\title{
Solubility of Sulfur in the Solid Oxide of the Calcium-Aluminate System
}

\author{
Sun-joong KIM, ${ }^{1)}$ Masaaki KAGEYAMA ${ }^{2)}{ }^{2} \mathrm{Xu} \mathrm{GAO}^{3 \mid *}$ Shigeru UEDA ${ }^{3)}$ and Shin-ya KITAMURA ${ }^{3)}$ \\ 1) Department of Materials Science and Engineering, College of Engineering, Chosun University, 309 Pilmun-daero, Dong-gu, \\ Gwangju, 61452 Korea. \\ 2) Graduate School of Engineering, Tohoku University. Now at Kakogawa Works, Kobe Steel Ltd., 1 Kanazawacho, Kakogawa, \\ Hyogo, 675-0137 Japan. \\ 3) Institute of Multidisciplinary Research for Advanced Materials, Tohoku University, 2-1-1 Katahira, Aoba-ku, Sendai, 980- \\ 8577 Japan.
}

(Received on March 5, 2019; accepted on May 7, 2019; J-STAGE Advance published date: June 22, 2019)

\begin{abstract}
The formation of $\mathrm{CaS}$ around $\mathrm{CaO}-\mathrm{Al}_{2} \mathrm{O}_{3}$ causes pitting corrosion in ferritic stainless steel. To prevent the precipitation of $\mathrm{CaS}$, the solubility of $\mathrm{CaS}$ in both the liquid and solid $\mathrm{CaO}-\mathrm{Al}_{2} \mathrm{O}_{3}$ system has to be clarified. In this study, the sulfur content in the $\mathrm{CaS}$-saturated solid $\mathrm{CaO}-\mathrm{Al}_{2} \mathrm{O}_{3}$ system was measured. The results showed that, sulfur was soluble only in $12 \mathrm{CaO} \cdot 7 \mathrm{Al}_{2} \mathrm{O}_{3}$ at approximately 1.2 mass $\%$ while the sulfur content in the other solid compounds was very low. In addition, the sulfur content of $12 \mathrm{CaO} \cdot 7 \mathrm{Al}_{2} \mathrm{O}_{3}$ was independent of the heating temperature and was higher than that in the liquid oxide of the same composition. Therefore, $12 \mathrm{CaO} \cdot 7 \mathrm{Al}_{2} \mathrm{O}_{3}$ can dissolve sulfur in the solid state, preventing CaS formation.
\end{abstract}

KEY WORDS: $\mathrm{CaO}-\mathrm{Al}_{2} \mathrm{O}_{3}$; CaS formation; solid compound; solubility of sulfur.

\section{Introduction}

The $\mathrm{CaO}-\mathrm{Al}_{2} \mathrm{O}_{3}$ system inclusion is generally formed by $\mathrm{Ca}$ addition or slag entrapment in Al-killed steel. Because of its low melting point, this type of inclusion is generally less harmful than $\mathrm{Al}_{2} \mathrm{O}_{3}$. However, when $\mathrm{CaS}$ is precipitated on this inclusion, it can cause pitting corrosion in ferritic stainless steel.

The formation of $\mathrm{CaS}$ around $\mathrm{CaO}-\mathrm{Al}_{2} \mathrm{O}_{3}$ oxides was observed in $\mathrm{Ca}$ added steel. Karino et $a{ }^{1)}{ }^{1)}$ analyzed the relationship between oxide composition and $\mathrm{Ca}$ content in the precipitated sulfide and concluded that $\mathrm{CaS}$ precipitated after the formation of the oxide. Takenouchi et al. ${ }^{2)}$ measured the solubility of $\mathrm{CaS}$ in liquid $\mathrm{CaO}-\mathrm{Al}_{2} \mathrm{O}_{3}$ at various temperatures and determined that the formation mechanism of $\mathrm{CaS}$ involved the precipitation from the liquid oxide by the decreased solubility of $\mathrm{CaS}$ at lower temperature.

On the other hand, in ferritic stainless steel, in some cases, $\mathrm{CaS}$ was observed without $\mathrm{Ca}$ addition. Kinoshita et $a l^{3)}$ and Yano et $a l^{4)}$ found that the origin of pitting corrosion was the precipitation of $\mathrm{CaS}$ and with increasing $[\mathrm{Al}]$ content, the degree of corrosion deteriorated despite the improvement of cleanliness. In addition, the authors showed that $\mathrm{CaS}$ was formed by the reaction of $2[\mathrm{Al}]+3[\mathrm{~S}]+3(\mathrm{CaO})=\left(\mathrm{Al}_{2} \mathrm{O}_{3}\right)+3 \mathrm{CaS}$. Kitamura et al. ${ }^{5)}$ observed $\mathrm{CaS}$ in ultra-low sulfur cold-rolled steel, where $\mathrm{CaS}$ was never observed in the molten steel or slab. The

\footnotetext{
* Corresponding author: E-mail: gao@tohoku.ac.jp

DOI: https://doi.org/10.2355/isijinternational.ISIJINT-2019-127
}

authors determined that $\mathrm{CaS}$ was formed after heating the slab, due to the diffusion of sulfur in the solid steel toward the $\mathrm{CaO}-\mathrm{Al}_{2} \mathrm{O}_{3}$ inclusion.

Many studies have focused on the solubility of $\mathrm{CaS}$ in liquid $\mathrm{CaO}-\mathrm{Al}_{2} \mathrm{O}_{3}$ system. The liquid composition saturated with CaS from $1698 \mathrm{~K}$ to $1899 \mathrm{~K}$ have been clarified, ${ }^{2,6-12)}$ and the thermodynamic modeling method has been established. ${ }^{12)}$ The sulphide capacity of molten $\mathrm{CaO}-\mathrm{Al}_{2} \mathrm{O}_{3}$ oxide has also been well measured. ${ }^{6-9,13-17)}$ However, the solubility of sulfur in the solid oxide of $\mathrm{CaO}-\mathrm{Al}_{2} \mathrm{O}_{3}$ system remains unknown. It is well known that the $\mathrm{CaO}-\mathrm{Al}_{2} \mathrm{O}_{3}$ binary system forms various stoichiometric compounds depending on the composition in solid state. To clarify the mechanism of $\mathrm{CaS}$ formation, the solubility of $\mathrm{CaS}$ in the solid oxide of the $\mathrm{CaO}-\mathrm{Al}_{2} \mathrm{O}_{3}$ system is important. In this study, the solubility of sulfur in various compounds of the $\mathrm{CaO}-\mathrm{Al}_{2} \mathrm{O}_{3}$ system was determined in the temperature range 1173 to $1573 \mathrm{~K}$.

\section{Experimental}

First, $\mathrm{CaO}-\mathrm{Al}_{2} \mathrm{O}_{3}-\mathrm{CaS}$ samples with various compositions were prepared. Reagent-grade $\mathrm{CaCO}_{3}, \mathrm{Al}_{2} \mathrm{O}_{3}$, and $\mathrm{CaS}$ were used, and $\mathrm{CaO}$ was produced by calcining $\mathrm{CaCO}_{3}$ at $1423 \mathrm{~K}$ for $24 \mathrm{~h}$ or longer. The reagents were mixed to the target composition and loaded in a vertical furnace using an $\mathrm{Al}_{2} \mathrm{O}_{3}$ or Pt crucible. After melting at $1723 \mathrm{~K}$ for $30 \mathrm{~min}$ under an Ar atmosphere, the crucible was removed from the furnace and quenched using He gas blowing. Because CaS was partially evaporated during melting, the sulfur content of the sample was analyzed using the combustion method 
Table 1. The composition of each sample mass $\%$.

\begin{tabular}{ccccc}
\hline & $\mathrm{CaO}$ & $\mathrm{Al}_{2} \mathrm{O}_{3}$ & $\mathrm{CaS}$ & Crucible \\
\hline HS-1 & 46.90 & 46.90 & 6.21 & $\mathrm{Al}_{2} \mathrm{O}_{3}$ \\
HS-2 & 42.54 & 51.99 & 5.47 & $\mathrm{Pt}$ \\
HS-3 & 52.35 & 42.83 & 4.82 & $\mathrm{Pt}$ \\
LS-1 & 49.03 & 49.03 & 1.94 & $\mathrm{Al}_{2} \mathrm{O}_{3}$ \\
LS-2 & 50.00 & 50.00 & 0.00 & $\mathrm{Pt}$ \\
\hline
\end{tabular}

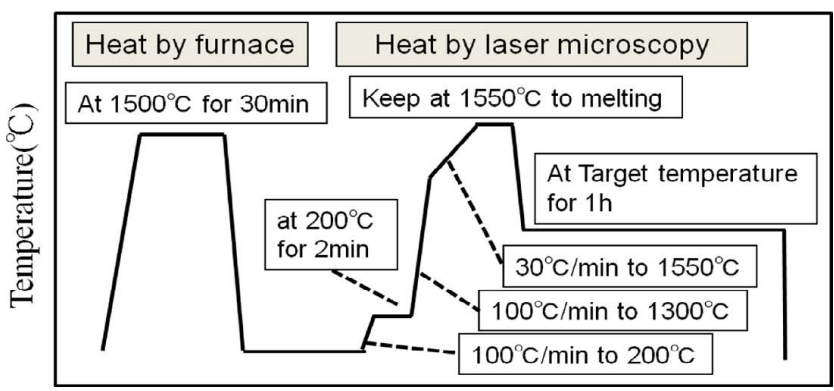

Fig. 1. Heating profile of the samples. (Online version in color.)

and the $\mathrm{CaS}$ content in the sample was calculated. The contents of $\mathrm{CaO}$ and $\mathrm{Al}_{2} \mathrm{O}_{3}$ were calculated assuming that their mass ratio was equal to the mixing ratio. Table 1 lists the sample compositions.

The samples were heated at 1 173-1 $573 \mathrm{~K}$ and monitored by confocal scanning laser microscopy (CSLM). The prepared samples were crashed into a powder with particles smaller than $50 \mu \mathrm{m}$, which was then used to form a $1 \mathrm{~mm}$ thick tablet approximately $6 \mathrm{~mm}$ in diameter. The formed tablet was inserted into the CSLM using a Pt crucible and heated under high purity Ar gas which passed through the glass tube with $\mathrm{Mg}$ power to eliminate residual oxygen.

The sample was heated at $473 \mathrm{~K}$ initially and kept for 2 min to eliminate moisture and subsequently heated to 1573 $\mathrm{K}$ at rate of $100 \mathrm{~K} / \mathrm{min}$, followed by heating to $1823 \mathrm{~K}$ at $30 \mathrm{~K} / \mathrm{min}$. The melting of the sample was identified by observation of its surface and when melting was detected, the sample was cooled to the holding temperature immediately and maintained for $10 \mathrm{~min}$ or $1 \mathrm{~h}$. In some cases, the sample was quenched after melting. The cooling rate was approximately $100-150 \mathrm{~K} / \mathrm{s}$ and the heating profile is shown in Fig. 1. After heating, the samples were quenched and their cross sections were observed by electron prove micro analyzer (EPMA).

\section{Results}

Typical mineralogical structures after heating for $1 \mathrm{~h}$ at $1473 \mathrm{~K}$ of samples HS-2 and 3 are shown in Figs. 2 and 3, respectively. In Fig. 2, the $12 \mathrm{CaO} \cdot 7 \mathrm{Al}_{2} \mathrm{O}_{3}$, $\mathrm{CaO} \cdot \mathrm{Al}_{2} \mathrm{O}_{3}, \mathrm{CaO} \cdot 2 \mathrm{Al}_{2} \mathrm{O}_{3}$, and $\mathrm{CaS}$ phases are shown. In Fig. 3, the $12 \mathrm{CaO} \cdot 7 \mathrm{Al}_{2} \mathrm{O}_{3}, 3 \mathrm{CaO} \cdot \mathrm{Al}_{2} \mathrm{O}_{3}$, and $\mathrm{CaS}$ phases were observed. The observed phases corresponded well with the equilibrium phase at the respective temperatures and the observation of $\mathrm{CaS}$ indicated that the sample compositions were saturated with $\mathrm{CaS}$. The sulfur content of $12 \mathrm{CaO} \cdot 7 \mathrm{Al}_{2} \mathrm{O}_{3}$ was approximately 1.3 mass $\%$, significantly higher than those of $\mathrm{CaO} \cdot \mathrm{Al}_{2} \mathrm{O}_{3}$ and $3 \mathrm{CaO} \cdot \mathrm{Al}_{2} \mathrm{O}_{3}$. Figure 4

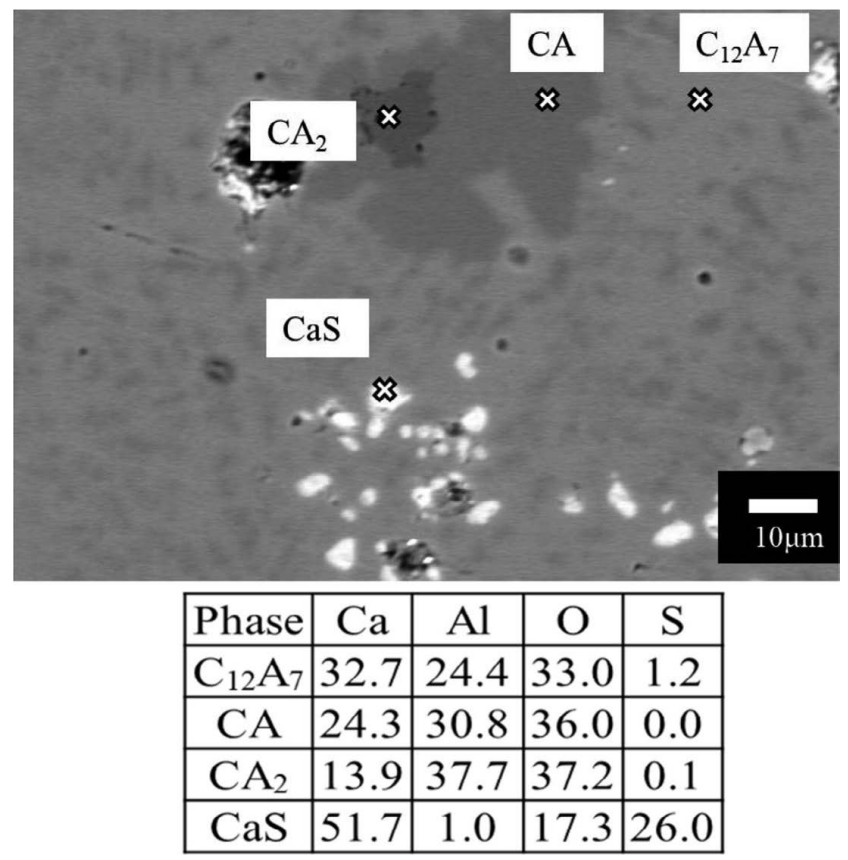

Fig. 2. Typical mineralogical structures of sample HS-2 after heating for $1 \mathrm{~h}$ at $1473 \mathrm{~K}$.

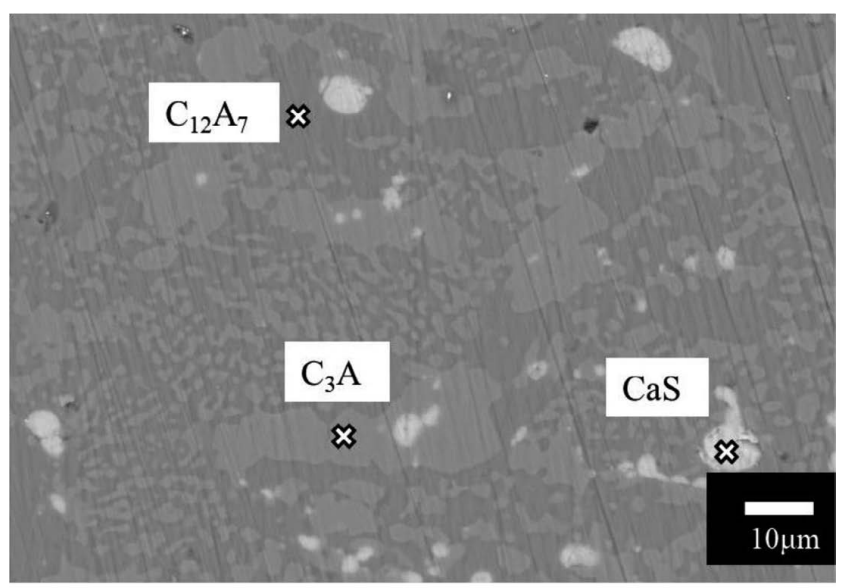

\begin{tabular}{|c|c|c|c|c|}
\hline Phase & $\mathrm{Ca}$ & $\mathrm{Al}$ & $\mathrm{O}$ & $\mathrm{S}$ \\
\hline $\mathrm{C}_{12} \mathrm{~A}_{7}$ & 34.1 & 25.3 & 36.6 & 1.3 \\
\hline $\mathrm{C}_{3} \mathrm{~A}$ & 43.9 & 19.0 & 36.3 & 0.1 \\
\hline $\mathrm{CaS}$ & 52.2 & 0.6 & 2.2 & 27.3 \\
\hline
\end{tabular}

Fig. 3. Typical mineralogical structures of sample HS-3 after heating for $1 \mathrm{~h}$ at $1473 \mathrm{~K}$.

shows the mineralogical structures after heating for $1 \mathrm{~h}$ at $1473 \mathrm{~K}$ for sample LS- 1 . In this case, the $12 \mathrm{CaO} \cdot 7 \mathrm{Al}_{2} \mathrm{O}_{3}$ and $\mathrm{CaO} \cdot \mathrm{Al}_{2} \mathrm{O}_{3}$ phases were observed but $\mathrm{CaS}$ was absent and the sulfur content of $12 \mathrm{CaO} \cdot 7 \mathrm{Al}_{2} \mathrm{O}_{3}$ was approximately one-half that observed in Figs. 2 and 3. In this sample, as the precipitation of $\mathrm{CaS}$ was not observed, it is likely that the oxide was not saturated with $\mathrm{CaS}$.

In Figs. 5 and 6, the influence of the holding temperature on the sulfur content in each phase is shown for samples rich in $\mathrm{CaO}$ (HS-3) and $\mathrm{Al}_{2} \mathrm{O}_{3}$ (HS-1 and 2), respectively. It is clear that the sulfur content of $12 \mathrm{CaO} \cdot 7 \mathrm{Al}_{2} \mathrm{O}_{3}$ was significantly higher than those observed in the other calcium-aluminate phases regardless of holding temperature. Figure 7 shows the influence of holding time at $1473 \mathrm{~K}$ 


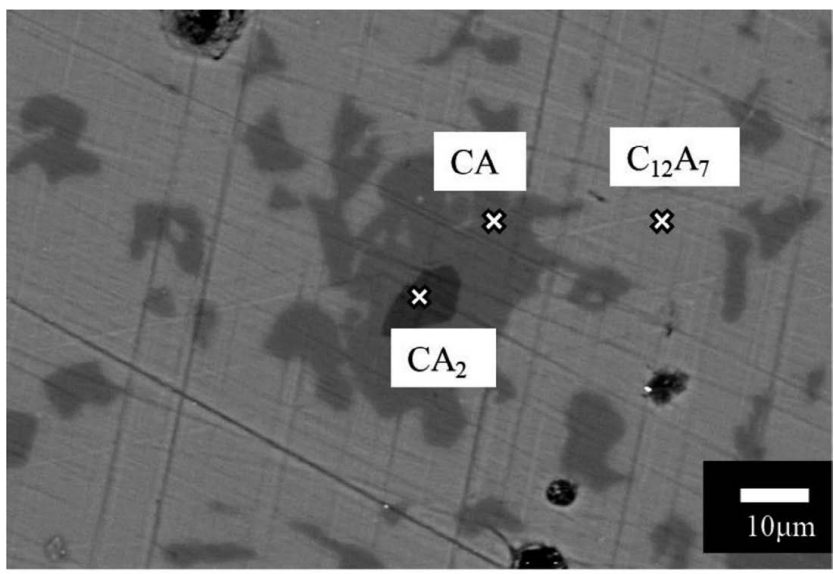

\begin{tabular}{|c|c|c|c|c|}
\hline Phase & $\mathrm{Ca}$ & $\mathrm{Al}$ & $\mathrm{O}$ & $\mathrm{S}$ \\
\hline $\mathrm{C}_{12} \mathrm{~A}_{7}$ & 32.8 & 24.9 & 34.8 & 0.6 \\
\hline $\mathrm{CA}$ & 24.2 & 31.2 & 37.3 & 0.0 \\
\hline $\mathrm{CA}_{2}$ & 14.8 & 38.2 & 39.0 & 0.0 \\
\hline
\end{tabular}

Fig. 4. Typical mineralogical structures of sample LS-1 after heating for $1 \mathrm{~h}$ at $1473 \mathrm{~K}$.

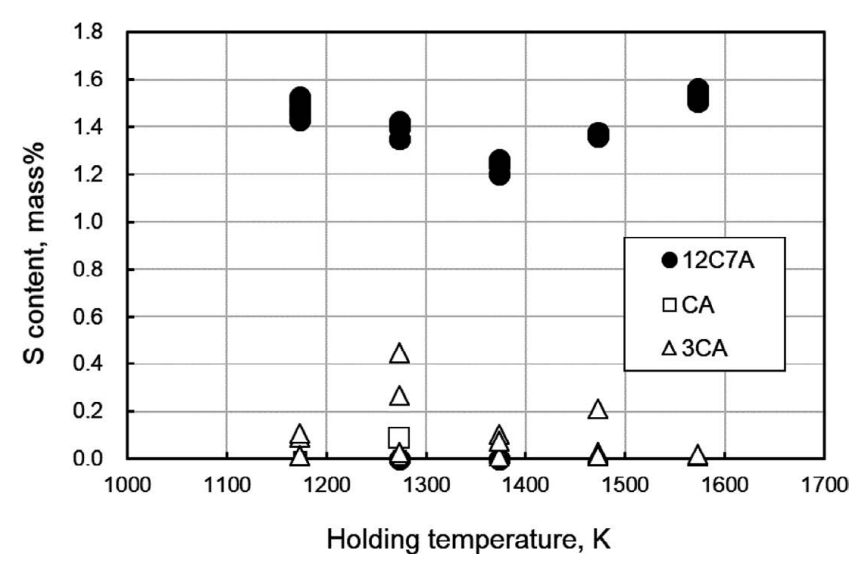

Fig. 5. Influence of the holding temperature on the sulfur content in each phase for the samples rich in $\mathrm{CaO}$ (HS-3).

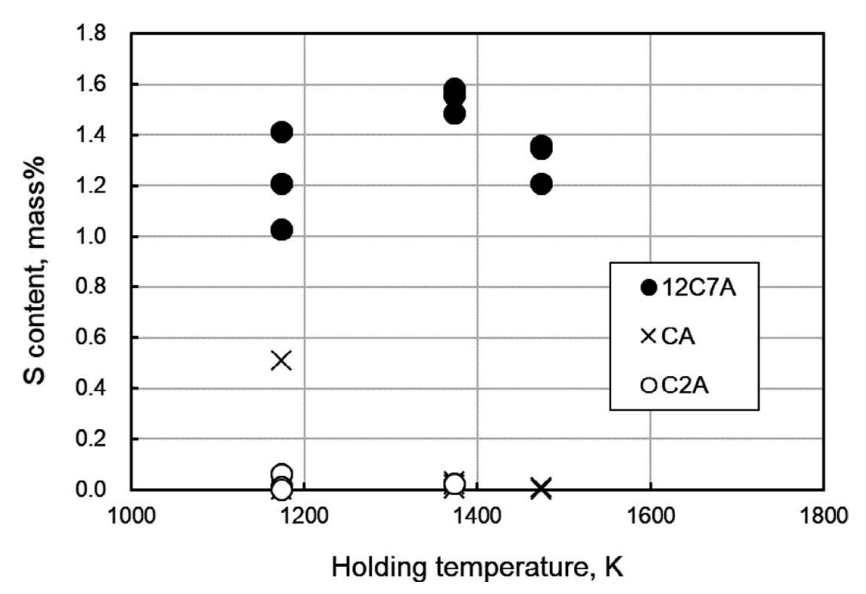

Fig. 6. Influence of the holding temperature on the sulfur content in each phase for the samples rich in containing $\mathrm{Al}_{2} \mathrm{O}_{3}$ (HS-1 and 2).

on the sulfur content in each phase. The sulfur content in the $12 \mathrm{CaO} \cdot 7 \mathrm{Al}_{2} \mathrm{O}_{3}$ phase gradually increased with increasing holding time, but even though the oxide quenched from $1823 \mathrm{~K}$, the sulfur content was approximately 0.9 mass $\%$.

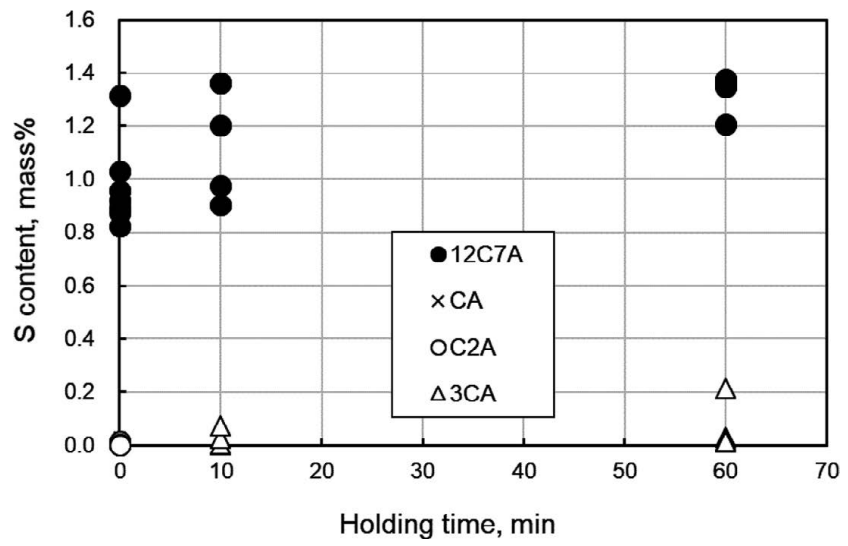

Fig. 7. Influence of the holding time at $1473 \mathrm{~K}$ on the sulfur content in each phase.

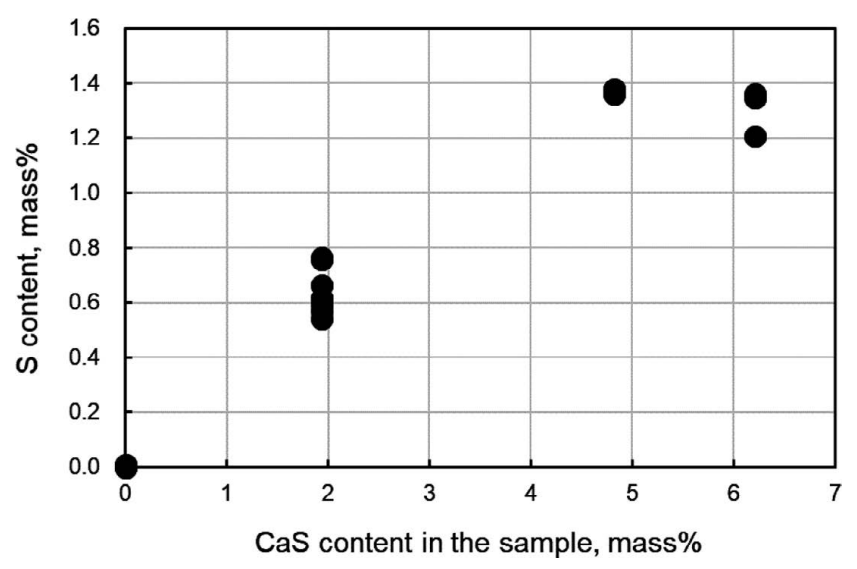

Fig. 8. Influence of $\mathrm{CaS}$ content in the sample on the sulfur content in $12 \mathrm{CaO} \cdot 7 \mathrm{Al}_{2} \mathrm{O}_{3}$.

As shown in Fig. 8, the sulfur content in the $12 \mathrm{CaO} \cdot 7 \mathrm{Al}_{2} \mathrm{O}_{3}$ phase was strongly influenced by the $\mathrm{CaS}$ content in the sample, but it saturated when the CaS content was increased to 4 mass $\%$ or more.

\section{Discussion}

The solubility of sulfur in liquid $\mathrm{CaO}-\mathrm{Al}_{2} \mathrm{O}_{3}$ oxide has been previously reported. Hino et al. measured the sulfide capacity (Cs; Eq. (1)) of the system at various temperatures $^{10,11)}$ and compared their results to those reported by other researchers. If the ratio of the partial pressure of $\mathrm{O}_{2}$ and $\mathrm{S}_{2}$ is fixed, the sulfur content in the oxide can be calculated using Eqs. (2) ${ }^{18)}$ and (3). ${ }^{18)}$ For the Al-killed steel, the activity of oxygen can be calculated using Eq. (4). ${ }^{18)}$

$$
\begin{gathered}
C_{S}=(\text { mass } \% S) \times\left(P_{O_{2}} / P_{S_{2}}\right)^{1 / 2} \ldots \ldots . . . \\
\frac{1}{2} O_{2}(g)=[O] \quad \log K_{O}=\frac{6120}{T}+0.18 \\
\frac{1}{2} S_{2}(g)=[S] \quad \log K_{S}=\frac{6540}{T}-0.96 .
\end{gathered}
$$

$$
2[\mathrm{Al}]+3[O]=\mathrm{Al}_{2} \mathrm{O}_{3}(s) \quad \log K_{A l}=\frac{64000}{T}-20.57 \ldots
$$

Assuming that the activity of aluminum is 0.05 or 0.025 and that of sulfur is 0.005 or 0.0025 , the equilibrium sulfur 


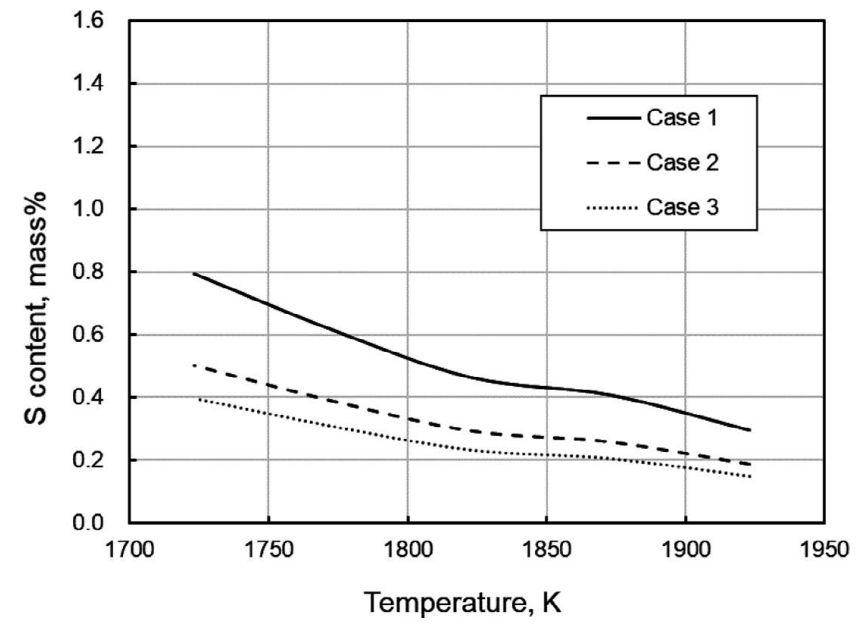

Fig. 9. Temperature dependence of the equilibrium sulfur content in the molten oxide.

content in the molten oxide was calculated and the results shown in Fig. 9. In this calculation, the sulfide capacity at 1823,1873 , and $1923 \mathrm{~K}$, the measured values were used and those at 1723 and $1773 \mathrm{~K}$ were estimated using the temperature dependence obtained from the Arrhenius equation. The activity of aluminum and sulfur in molten steel are 0.05 and 0.005 for case $1 ; 0.025$ and 0.005 for case 2; and 0.05 and 0.0025 for case 3 , respectively. Considering the normal grade of Al killed steel, the activity of Al was assumed as 0.0025 and 0.05 . In the case to suppress the formation of $\mathrm{CaS}$, desulfurization is generally conducted in the secondary refining. Therefore, the activity of sulfur was assumed as 0.005 and 0.0025 . From Fig. 9, the sulfur content depends on the activities of aluminum and sulfur, but the observed sulfur content in the $12 \mathrm{CaO} \cdot 7 \mathrm{Al}_{2} \mathrm{O}_{3}$ phase in the solid oxide is larger than that in the molten oxide of the sample with identical composition.

The $12 \mathrm{CaO} \cdot 7 \mathrm{Al}_{2} \mathrm{O}_{3}$ phase is known to be an electrically conductive oxide ceramic. ${ }^{19-21)}$ Its crystal has a unique subnanoporous structure composed of 12 positively charged cages, including two free oxygen ions which maintain electrical neutrality. The free oxygen ions can be exchanged with an anion, X (i.e. fluorine or chlorine), according to the following reactions:

$$
\begin{aligned}
{\left[\mathrm{Ca}_{24} \mathrm{Al}_{28} \mathrm{O}_{64}\right]^{4+}\left(2 \mathrm{O}^{2-}\right)+4 \mathrm{X}^{-}=} & {\left[\mathrm{Ca}_{24} \mathrm{Al}_{28} \mathrm{O}_{64}\right]^{4+}\left(4 \mathrm{X}^{-}\right) } \\
& +2 \mathrm{CaO}
\end{aligned}
$$

If the exchange reaction with sulfide is considered, the following equation can be written:

$$
\begin{aligned}
{\left[\mathrm{Ca}_{24} \mathrm{Al}_{28} \mathrm{O}_{64}\right]^{4+}\left(2 \mathrm{O}^{2-}\right)+2 \mathrm{CaS} } & =\left[\mathrm{Ca}_{24} \mathrm{Al}_{28} \mathrm{O}_{64}\right]^{4+}\left(2 \mathrm{~S}^{2-}\right) \\
& +2 \mathrm{CaO}
\end{aligned}
$$

From the mass balance calculations, if all free oxygen sites are replaced by sulfur ions, the sulfur content would increase to 2.28 mass $\%$. Therefore, the observed sulfur content in this study is reasonable.

To suppress the formation of $\mathrm{CaS}$ from the inclusion of calcium-aluminate, the phase ratio of $12 \mathrm{CaO} \cdot 7 \mathrm{Al}_{2} \mathrm{O}_{3}$ in the solid state is an important factor to consider. Because when the mass ratio of this oxide to solid steel is enough large, sulfur can be dissolved in this oxide and the formation of $\mathrm{CaS}$ can be suppressed.

\section{Conclusions}

The sulfur content in the CaS-saturated $\mathrm{CaO}-\mathrm{Al}_{2} \mathrm{O}_{3}$ system was measured and the results can be summarized as follows:

(1) In the $\mathrm{Al}_{2} \mathrm{O}_{3}$-rich oxide, $\mathrm{CaO} \cdot \mathrm{Al}_{2} \mathrm{O}_{3}, 12 \mathrm{CaO} \cdot 7 \mathrm{Al}_{2} \mathrm{O}_{3}$, and $\mathrm{CaS}$ phases were observed, whereas the dominant phases in the $\mathrm{CaO}$-rich oxide were $12 \mathrm{CaO} \cdot 7 \mathrm{Al}_{2} \mathrm{O}_{3}, 3 \mathrm{CaO} \cdot \mathrm{Al}_{2} \mathrm{O}_{3}$, and $\mathrm{CaS}$.

(2) Sulfur was dissolved only in $12 \mathrm{CaO} \cdot 7 \mathrm{Al}_{2} \mathrm{O}_{3}$ at approximately 1.2 mass \% while the sulfur content in the other oxides was very low.

(3) The sulfur content in $12 \mathrm{CaO} \cdot 7 \mathrm{Al}_{2} \mathrm{O}_{3}$ was independent of the heating temperature and was higher than that in the liquid oxide of the same composition.

Based on the experimental results, it is clear that $12 \mathrm{CaO} \cdot 7 \mathrm{Al}_{2} \mathrm{O}_{3}$ can dissolve sulfur in the solid state, preventing $\mathrm{CaS}$ formation.

\section{Acknowledgement}

This work was performed under the Research Program "Dynamic Alliance for Open Innovation Bridging Human, Environment and Materials".

\section{REFERENCES}

1) T. Kano and T. Hanyuda: Denki-Seiko, 75 (2004), 27 (in Japanese).

2) T. Takenouchi and K. Suzuki: Tetsu-to-Hagané, 63 (1977), 1653 (in Japanese).

3) N. Kinoshita, N. Ohashi and M. Takeda: Trans. Iron Steel Inst. Jpn., 16 (1976), 251.

4) S. Yano, K. Nakanishi, H. Ooi, K. Fujimoto and S. Iwaoka: Trans. Iron Steel Inst. Jpn., 16 (1976), 258.

5) S. Kitamura: Proc. 7th Int. Symp. on Molten Slags, Fluxes and Salts, The South African Institute of Mining and Metallurgy, Johannesburg, (2004), 769.

6) R. A. Sharma and F. D. Richardson: J. Iron Steel Inst., 198 (1961), 386.

7) J. Cameron, T. B. Gibbons and J. Taylor: J. Iron Steel Inst., 204 (1966), 1223.

8) B. Ozturk and E. T. Turkdogan: Met. Sci., 18 (1984), 299.

9) G. J. W. Kor and F. D. Richardson: J. Iron Steel Inst., 206 (1968), 700 .

10) T. Fujisawa, S. Inoue, S. Takagi, Y. Wanibe and H. Sakao: Tetsu-toHagané, 71 (1985), 839 (in Japanese).

11) H. Fukaya and T. Miki: ISIJ Int., 51 (2011), 2007.

12) R. Piao, H. Lee and Y. Kang: Acta Mater., 61 (2013), 683.

13) C. J. B. Fincham and F. D. Richardson: J. Iron Steel Inst., 178 (1954),

14) P. T. Carter and T. G. Macfarlane: J. Iron Steel Inst., 185 (1957), 54.

15) E. Schürmann, R. Bruder, K. Nürnberg and H. Richter: Arch. Eisenhüttenwes., 50 (1979), 139.

16) M. Hino, S. Kitagawa and S. Ban-ya: ISIJ Int., 33 (1993), 36.

17) S. Ban-ya, M. Hobo, T. Kaji, T. Itoh and M. Hino: ISIJ Int., 44 (2004), 1810.

18) Steelmaking Data Sourcebook, ed. by The 19th Committee on Steelmaking, The Japan Society for the Promotion of the Science, Gordon and Breach, New York, (1988), 203.

19) R. W. Nurse, J. H. Welch and A. J. Majumdar: Trans. J. Br. Ceram. Soc., 64 (1965), 409.

20) K. Hayashi, S. Matsuishi, T. Kamiya, M. Hirano and H. Hosono: Nature, 419 (2002), 462.

21) S. Matsuishi, Y. Toda, M. Miyakawa, K. Hayshi, T. Kamiya, M. Hirano, I. Tanaka and H. Hosono: Science, 301 (2003), 626. 